Review

\title{
Cancer Hallmarks, Biomarkers and Breast Cancer Molecular Subtypes
}

\author{
Xiaofeng Dai ${ }^{\bowtie}$, Liangjian Xiang, Ting Li, Zhonghu Bai \\ National Engineering Laboratory for Cereal Fermentation Technology, School of Biotechnology, Jiangnan University, Wuxi, Jiangsu, P.R.China. \\ $\triangle$ Corresponding author: Xiaofeng Dai, PhD, National Engineering Laboratory for Cereal Fermentation Technology, School of Biotechnology, Jiangnan \\ University, No. 1800, Lihu Avenue, Wuxi 214122, P.R.China. E-mail: Xiaofeng.dai@me.com, Tel.: +86-18611479958, Fax: +86-0510-85329306. \\ (C) Ivyspring International Publisher. Reproduction is permitted for personal, noncommercial use, provided that the article is in whole, unmodified, and properly cited. See \\ http://ivyspring.com/terms for terms and conditions.
}

Received: 2015.07.05; Accepted: 2016.05.19; Published: 2016.06.23

\begin{abstract}
Breast cancer is a complex disease encompassing multiple tumor entities, each characterized by distinct morphology, behavior and clinical implications. Besides estrogen receptor, progesterone receptor and human epidermal growth factor receptor 2, novel biomarkers have shown their prognostic and predictive values, complicating our understanding towards to the heterogeneity of such cancers. Ten cancer hallmarks have been proposed by Weinberg to characterize cancer and its carcinogenesis. By reviewing biomarkers and breast cancer molecular subtypes, we propose that the divergent outcome observed from patients stratified by hormone status are driven by different cancer hallmarks. 'Sustaining proliferative signaling' further differentiates cancers with positive hormone receptors. 'Activating invasion and metastasis' and 'evading immune destruction' drive the differentiation of triple negative breast cancers. 'Resisting cell death', 'genome instability and mutation' and 'deregulating cellular energetics' refine breast cancer classification with their predictive values. 'Evading growth suppressors', 'enabling replicative immortality', 'inducing angiogenesis' and 'tumor-promoting inflammation' have not been involved in breast cancer classification which need more focus in the future biomarker-related research. This review novels in its global view on breast cancer heterogeneity, which clarifies many confusions in this field and contributes to precision medicine.
\end{abstract}

Key words: cancer hallmarks, biomarker, breast cancer, subtype.

\section{Introduction}

Breast cancer is the most common neoplasm among women in the majority of the developed countries, accounting for one-third of newly diagnosed malignancies [1]. It is a highly heterogeneous disease, encompassing a number of biologically distinct entities with specific pathologic features and biological behaviors [1, 2]. Different breast tumor subtypes have different risk factors, clinical presentation, histopathological features, outcome, and response to systemic therapies [3-8]. Thus, stratification of breast cancer by clinically relevant subtypes is urgently required.

Immunohistochemistry (IHC) markers, together with clinicopathological variables such as tumor size, tumor grade, nodal involvement, histologic type, and surgical margins, have been widely used for prognosis, prediction and treatment selection $[9,10]$. Back to 1970s, breast cancer was divided into two subtypes according to the status of estrogen receptor (ER). With the advent of new technologies and incremental understanding of the complex tumorigenesis progress, new biomarkers and novel subtypes have been kept identified. This, on one hand, helps us in more accurate disease management, but, on the other hand, complicates our understanding towards breast cancer heterogeneity.

In 2000, Weinberg et al. have reported six hallmarks of cancer, i.e., 'sustaining proliferative signaling', 'evading growth suppressors', 'resisting cell death', 'enabling replicative immortality', 
'inducing angiogenesis', and 'activating invasion and metastasis' [11]. The same authors have identified two emerging hallmarks, i.e., 'reprogramming of energy metabolism' and 'evading immune destruction', in 2011, and pointed out that all these hallmarks are enabled by two characteristics, i.e., 'genome instability and mutation' and 'tumor-promoting inflammation' [12]. As tumors are not conceivable as a single disease, breast cancer with different diagnostic features should differ in the hallmarks controlling their clinical differences. This review aims at identifying these dominant hallmarks driving breast cancer heterogeneity by focusing on identified biomarkers and the associated subtypes.

\section{Hallmark 1: Sustaining proliferative signaling}

\section{Hormonal and growth receptors define basic breast tumor molecular subtypes}

IHC markers including ER, progesterone receptor (PR) and human epidermal growth factor receptor 2 (HER2) are classically used for breast tumor subtyping [13]. Experiments testing these markers have been routinely carried out in pathology laboratories, with staining and evaluation protocols well established worldwide [1]. These hormonal and growth receptors are known to mediate cell growth signaling. For instance, estrogen promotes the development of breast cancer and stimulates the growth in vitro of breast cancer cell lines having the corresponding receptors [14, 15]. Breast tumors are grouped into four basic subgroups according to these markers, i.e., $[\mathrm{ER}+\mid \mathrm{PR}+]$ HER2- (tumors with either ER or PR positivity, and HER2 negativity), [ER+|PR+]HER2+ (tumors with either ER or PR positivity, and HER2 positivity),

ER-PR-HER2+ (tumors with ER and PR negativity, and HER2 positivity, also named HER2 positive), ER-PR-HER2- (tumors with ER, PR, HER2 negativity, also named triple negative). In this naming system, hormonal receptors (HR) are shown in the square brackets, 'I' represents 'or', and ' $+/-$ ' shows the receptor status [1]. In general, ER-PR- tumors (tumors with both ER and PR negativity) have relatively poorer prognosis than $[\mathrm{ER}+\mid \mathrm{PR}+]$ cancers (tumors with either ER or PR positivity).

\section{ER}

$\mathrm{ER}$ is the most important and prevalent biomarker for breast cancer classification. It was first identified in the 1960s and used in breast cancer clinical management since mid-1970s as a primary indicator of endocrine responsiveness and a prognostic factor for early recurrence [16]. ER plays crucial roles in breast carcinogenesis, whose inhibition forms the mainstay of breast cancer endocrine therapy. ER status has been shown to be the major determinant of breast cancer molecular portraits by recent gene expression profiling (GEP) studies [17-21]. It is comprised in the UK minimum data set for histopathology reporting of invasive breast cancer and routinely determined by a standardized technique [22].

ER positive tumors comprise up to $75 \%$ of all breast cancer patients, and constitute $65 \%$ and $80 \%$, respectively, patients under and above 50 years [23]. ER positive tumors are largely well-differentiated, less aggressive, and associated with better outcome after surgery [24] than ER-negative ones [25]. Though ER alone provides limited prognostic value given the little difference on patients' long-term survival stratified by its status [26], it has been considered as the most powerful single predictive factor identified in breast cancer [20, 26-28]. In general, ER negative tumors are unlikely to respond to endocrine therapy, and approximately $50 \%$ ER positive patients are responsive to anti-estrogen or aromatase inhibitors [29]. A small proportion of ER negative tumors are documented to respond to hormonal therapy [30, 31]. Breast tumors differing in ER status are fundamentally different at the transcriptional level [17-19, 32], complexity of genetic aberrations [33-35], as well as the pathways and networks $[17,35,36]$. Besides ER, the importance of other biomarkers have been continuously reported in breast tumor subtyping with respect to their risk factors, clinical and biological behaviors $[7,29,31]$.

\section{PR}

$\mathrm{PR}$ is induced by endocrine, whose activation suggests an active ER signaling [37-40]. PR positive tumors comprise $65 \%$ to $75 \%$ breast cancers and several studies have suggested its clinical implications in the classification of such tumors [41-46]. However, its classification role has been questioned by several researchers due to the lack of evidence supporting its predictive role over ER on endocrine therapeutic response [26, 29, 47]. PR positive tumors are hardly ER negative [47], i.e., $0.2 \%$ to $10 \%$ depending on the detection methods [16, 48-52]. Thus, strong PR positivity in an ER negative case may indicate a false discovery on ER negativity, which is commonly encountered in routine practice [50]. As demonstrated by Dowsett et al. [31], ER-PR+ patients benefit from endocrine therapy which would be excluded from such treatment if the decision was based on ER status alone. Approximately 40\% ER positive tumors are PR negative [53]. ER+PR- tumors are less responsive to endocrine treatment than ER+PR+ tumors [53-56], 
particularly for metastatic tumors under tamoxifen treatment [44, 45]. Lacking PR expression in ER positive tumors may suggest aberrant growth factor signaling that, in turn, contributes to tamoxifen resistance of such tumors [53-56]. PR is conventionally used together with ER in breast tumor subtyping, i.e., $\mathrm{ER}+\mathrm{PR}+, \mathrm{ER}+\mathrm{PR}-, \mathrm{ER}-\mathrm{PR}+, \mathrm{ER}-\mathrm{PR}-$ are classified. The double positive group (ER+PR+) comprises $55 \%$ to $65 \%$ of breast tumors $[24,53,57]$, among which $75 \%$ to $85 \%$ are responsive to endocrine treatment [31]. Compared with the other subgroups, patients of these tumors are associated with older age, lower grade, smaller tumor size and lower mortality rate. The double negative group (ER-PR-) comprises 18\% to $25 \%$ of the tumors, among which around $85 \%$ are of grade 3 . These tumors are associated with a higher recurrence rate, lower overall survival and do not respond to endocrine therapy [44, 45, 54, 57-59]. Tumors with concurrent negativity of ER and PR have, in general, good response to preoperative taxane/anthracycline-based regimen. Lots of evidences indicate that tumors of this class are highly heterogeneous [7, 60], which could be sub-divided into many groups based on the status of other markers such as HER2 [19, 20]. The single positive phenotype is consist of ER+PR- and ER-PR+ tumors, each accounting for $12 \%$ to $17 \%$ [24, 53, 57] and $0.2 \%$ to $10 \%$ breast cancer patients. Compared with double positive tumors, these cancers are more often of higher histological grade, larger tumor size, and are more likely to be aneuploidy and show higher expression of proliferation-related genes such as epidermal growth factor receptor (EGFR) and HER2 $[53,55]$. Tumors with single hormone receptor positivity respond less well to endocrine treatment than those harboring double positive receptors [44, 54, 61], with only $40 \%$ responding to hormonal manipulation [31]. The single positive group is reported to show biological features somewhere in between the double positive and double negative groups $[53,62,63]$.

Instead of using the binary representation, i.e., positive and negative, to define the receptor status in subtyping, the expression levels of ER and PR have been used to predict tumors' response to endocrine therapy [64]. Two categories of ER+PR+ tumors are reported, i.e., tumors over-expressing both ER and PR (ER $>50 \%$ and $\mathrm{PR}>50 \%$ ) and tumors expressing low levels of either or both receptors $(10 \%<\mathrm{ER}<50 \%$ or PR $<50 \%$ ), where the first category is highly sensitive to hormone treatment and the second is incompletely endocrine responsive [64]. The ER-/PR- group (ER < $10 \%$ and $\mathrm{PR}<10 \%$ ), on the other hand, is not shown to be beneficial from endocrine therapy [64]. A meta-analysis shows that the benefit of women from 5 years' tamoxifen treatment is proportional to the level of ER [29]. Further, Stendahl et al. recommend the use of a fractioned rather than dichotomized immunohistochemical evaluation of both ER and PR in the clinical practice [42].

Taken together, joint ER, PR assessment differentiates breast cancer variants better than using either one alone. Breast cancer subtypes classified by the two receptors can be ordered by ER+PR+, ER+PR-, ER-PR+, ER-PR-, with ER+PR+ being the most favorable and ER-PR- the most aggressive cancers regarding tumor size, grade, stage, patient outcome and response to hormonal therapies [24, 44, $45,53-57,65]$.

\section{HER2}

The clinical implications of HER2 amplification have been recognized since 1987 [66]. Numerous subsequent studies have revealed that HER2 gene amplification or protein over-expression is associated with poor prognosis and good clinical outcome receiving systemic chemotherapy treatment [67-69]. The protein over-expression and gene amplification of HER2 occur in $13 \%$ to $20 \%$ of invasive ductal breast cancer, more than half of which (around 55\%) are ER-PR- [66, 70, 71]. The prognostic value of HER2 positivity is higher in node-positive than node-negative patients. Examining HER2 status has been established as a routine clinical practice before applying trastuzumab to advanced tumors or adjuvant treatment to potential HER2 positive early stage patients [72, 73]. Its predictive value on the outcome receiving anthracycline-based chemotherapy has been reported, with HER2 positivity being associated with favorable drug response [74-77]. It has also been suggested that HER2 positivity is predictive of better response to higher dose of anthracycline related regimens $[78,79]$, and to regimens containing taxane than those do not [80, 81]. Besides, HER2 positivity is associated with relative but not absolute resistance to endocrine therapies [82], which is consistent with the inverse relationship of HER2 and ER/PR at the expression level [71]. Note that such resistance does not apply to estrogen depletion therapies such as aromatase inhibitors [83, 84]. Despite the aforementioned treatments and strategies, HER2 is an important target of a variety of novel cancer therapies, including vaccines and drug lapatinib which is directed at the internal tyrosine kinase portion of HER2 protein.

A combination of various IHC markers including ER, PR and HER2, with or without additional markers such as basal and proliferation markers, has been used to define breast tumor subtypes, where the statuses of ER, PR and HER2 
have been considered as the most important features. Using the dichotomized immunohistochemical evaluation of these three receptors, breast tumors could be classified into [ER+|PR+]HER2-, $[$ ER+ $\mid$ PR+]HER2+, ER-PR-HER2+, and ER-PR-HER2-. [ER+ $\mid \mathrm{PR}+]$ HER2-

and [ER+|PR+]HER2+ are similar to luminal $A$ and luminal $\mathrm{B}$ tumors defined by GEP nomenclature [85-89]. However, no unanimous consensus has been reached on such conversion between IHC and GEP classification. In Nielsen's study, all HER2+ cases $([\mathrm{ER}+\mid \mathrm{PR}+] \mathrm{HER} 2+$, ER-PR-HER2+) are grouped as HER2 positive subclass [90], based on the evidence that HER2-amplified cases share similar genetic changes [91] and outcome [9, 18, 85] regardless of their hormonal statuses.

Preclinical and clinical data suggest that HER2 over-expression confers intrinsic resistance to hormonal treatment in ER+ or PR+ tumors, indicating that $[\mathrm{ER}+\mid \mathrm{PR}+]$ HER2+ tumors may not benefit much from single-agent hormone therapy. Results from randomized clinical trials combining hormone treatment and targeted anti-HER2 therapy in $[\mathrm{ER}+\mid \mathrm{PR}+] \mathrm{HER} 2+$ postmenopausal patients indicate that this novel dual-targeting strategy could significantly improve patient outcome [92]. Konecny et al. find that HER2 expression is inversely correlated with that of ER, and suggest that the relative resistance of $[\mathrm{ER}+\mid \mathrm{PR}+]$ HER2+ tumors to hormone therapy as compared with the $[\mathrm{ER}+\mid \mathrm{PR}+]$ HER2subtype is due to reduced ER or PR expression or high proliferation rates rather than HER2 positivity [82]. Other studies suggest that $[\mathrm{ER}+\mid \mathrm{PR}+] \mathrm{HER} 2+$ breast cancer might benefit more from anti-HER2 therapy plus chemotherapy [93]. It is reported that $[\mathrm{ER}+\mid \mathrm{PR}+]$ HER2+ tumors have a good prognosis irrespective of the achievement of a pathological complete response (defined as the absence of any residual invasive cancer at the breast site and at the nearest axillary lymph node site [94]), whereas patients with ER-PR-HER2+ and ER-PR-HER2tumors show the worst prognosis [95]. Hayes et al. have demonstrated that HER2+ tumors benefit from the addition of paclitaxel after adjuvant treatment with doxorubicin plus cyclophosphamide in node-positive breast cancer regardless of ER status, while ER+HER2- tumors gain little benefit from such treatment [81].

All current evidences indicate that $[E R+\mid P R+]$ HER2- tumors have the best prognosis and response to hormone therapy. ER-PR-HER2+ and ER-PR-HER2- tumors are poorly differentiated, show aggressive behavior and poor outcome, and are least likely to respond to hormone therapy.

\section{AR}

Besides ER, PR and HER2, androgen receptor (AR) has also been used in breast cancer subtyping. $\mathrm{AR}$ is the prevalent sex steroid hormone receptor expressed in 90\% ER positive and 55\% ER negative tumors [96, 97]. It is a potential prognostic marker and therapeutic target in breast cancer. It seems to play a similar role as HER2. Lakes et al. have classified ER-PR- tumors into ER-PR-AR+ (molecular apocrine, abbreviated as MAC) and hormone receptor negative carcinomas (ER-PR-AR-) [32, 98], and a considerable overlap is observed between ER-PR-HER2+ and MAC tumors [98]. MAC accounts for $13.2 \%$ of all breast cancer cases and is often characterized by KI67+ [98]. Despite the higher risk of ER-PR- tumors regarding patient relapse and death, MAC tumors have a favorable outcome comparable with $[\mathrm{ER}+\mid \mathrm{PR}+]$ tumors $[32,98]$. Also, patients with MAC tumors have a favorable outcome on treatment containing taxane $[32,98]$.

Taken together, the classic breast tumor molecular subtypes are defined by hormonal and growth receptors according to the most prominent cancer hallmark, i.e., 'sustaining proliferative signaling'. With the decreasing response to proliferative signals, breast tumors exhibit increasing aggressiveness and decreasing number of available targeted therapy. Among the three hormonal receptors (ER, PR, AR) and the growth receptor (HER2), ER plays a determinant role on differentiating breast tumors regarding their proliferation ability (corresponding to the 'sustaining proliferative signaling'), while PR and AR exhibit a similar role with ER and HER2, respectively.

\section{Proliferation markers deteriorate [ER+|PR+]HER2- tumors}

More directly than hormonal receptors, proliferation markers have been used in breast tumor classification, especially among [ER+|PR+]HER2tumors. It has been widely acknowledged that increased cell proliferation is a key determinant of clinical outcome among breast cancer patients [99, 100]. Chemotherapy agents including CMF (cyclophosphamide, methotrexate, 5-fluorouracil), taxanes and anthracycline-based treatment all affect cell division or DNA synthesis. Thus, concurrent assessment of proliferation and conventional IHC markers provides additional predictive value and more precise clinical implications than using IHC alone. Worth noting that proliferation markers are informative in further differentiating HR positive tumors and of limited value in ER-PR-HER2- or HER2 positive tumor classification [88]. 


\section{KI67}

The most widely used proliferation marker in breast cancer is KI67, which is predominantly present in cycling cells [101]. KI67 has been used to predict the neoadjuvant response [102-106] or outcome from adjuvant chemotherapy (endocrine therapy for ER positive tumors) for breast cancer. It has also been used in combination with other markers in breast cancer to provide prognostic and predictive values [9, $105,107]$. Chang et al. have used KI67 in addition to ER, PR and HER2 to classify breast tumors, where $[\mathrm{ER}+\mid \mathrm{PR}+]$ tumors are divided into three prognostically distinct subclasses based on the expression of KI67 and HER2 [9]. In their study, $[\mathrm{ER}+\mid \mathrm{PR}+]$ HER2- tumors are classified into [ER+ |PR+]HER2-KI67- and [ER+|PR+]HER2-KI67+ tumors, respectively, with [ER+|PR+]HER2-KI67+ being associated with poorer outcome regardless of systemic therapy [9]. This accords with the hallmark of cancer on 'sustaining proliferative signaling', with the more propensity on cancer cell proliferation the poorer patient clinical outcome. This classification subdivides the intrinsic luminal B tumors (as will be described in the next section) into two groups, i.e., $[$ ER+ $\mid$ PR+]HER2-KI67+ and [ER+ PR+]HER2+ $\mathrm{KI} 67+$, demonstrating the importance of the combined use of KI67 with ER, PR, HER2 in differentiating tumors with positive hormone receptors. Further, the joint use of these four markers has been shown to provide as much information as some expensive molecular assays in breast cancer subtyping [92].

\section{TOP2A}

Topoisomerase II alpha (TOP2A) catalyzes the breakage and reunion of double-stranded DNA, and thus leads to relaxation of DNA supercoils [108]. It plays crucial roles in a number of fundamental nuclear processes including DNA replication, transcription, chromosome structure, condensation and segregation [108], thus heavily affects cell proliferation. TOP2A expression is found correlated with that of KI67 [109, 110]. TOP2A aberration is frequently found in HER2-amplified breast cancer, accounting for approximately 30\%-90\% of such tumors. It has been suggested as a potential biomarker with aberrations being associated with increased responsiveness to anthracycline-based chemotherapy [108, 111-113].

\section{Cell cycle genes}

Aside from KI67, other proliferation markers have also demonstrated their importance in differentiating $[\mathrm{ER}+\mid \mathrm{PR}+]$ tumors. Cell cycle genes are known to be associated with proliferation, whose over-expression is prognostic of poor clinical outcome. Loi et al. have identified a 97-gene signature, mostly comprising genes involved in cell cycle regulation and proliferation [114]. Using these genes they classified $[\mathrm{ER}+\mid \mathrm{PR}+]$ tumors into two groups significantly differ in prognosis despite whether or not tamoxifen is given [115]. Perou et al. have reported that a cluster of genes, whose expression considerably vary among subtypes, are correlated with cellular proliferation rates [18, 87].

Taken together, over-expression of proliferation markers tend to accelerate the hallmark of 'sustaining proliferative signaling' among [ER+|PR+]HER2tumors, leading to worse clinical outcome.

\section{Hallmark 2: activating invasion and metastasis}

\section{Basal markers deteriorate ER-PR-HER2- tumors}

ER-PR-HER2- tumors are undeniably one of the most relevant subtypes among breast tumors given the lack of targeted therapies and their aggressive clinical behavior. These patients can be clustered into at least two distinct molecular classes, i.e., the basal phenotype and non-basal ER-PR-HER2- tumors [85, 89, 90, 116-119], which differ in their behavior, outcome and therapeutic response. An expanding number of basal IHC markers have been used to define the basal tumors, among which cytokeratins (CK) 5/6, 14, 17, 8/18, EGFR are the most widely accepted [13, 85, 89, 90, 118-123]. Various combinations of these basal markers have been used to identify the basal subtype. The most pragmatic and widely accepted definition of the basal subtype is ER-PR-HER2- tumors with positive expression of CK5/6 and EGFR [85, 123]. Rakha et al. have proposed the use of CK5/6, CK14, CK17 and EGFR in characterizing basal tumors from ER-PR-HER2cancers [118]. Matos et al., have reported the combined assess of P-cadherin, TP63 and CK5 in distinguishing the basal subtype from ER-PR-HER2tumors via immunoprofiling [89]. The basal subtype has also been identified from double negative (ER-HER2-) tumors using basal markers. Nielsen et al. have used CK5/ 6 and EGFR to identify basal tumors from hormone receptor negative cancers regardless of PR status [90]. In addition to CK5/ 6 and EGFR, Livasy et al. have added CK8/18 and vimentin (VIM) in their panel to characterize such tumors within the ER-HER2- group [124]. Cytokeratins alone have been used to identify the basal subtype. For instance, CK5/6 and CK14 have been jointly assessed to identify the basal subtype [120], and CK14 alone is reported to define a proportion of breast tumors carrying morphological features strongly associated 

identifying the basal subgroup from ER-PR-HER2breast tumors in various publications are summarized

Despite the various inclusions of basal markers in triple negative breast tumor classification, markers of this class are associated with the cancer hallmark of 'invasion and metastasis'. Recent studies have shown that cytokeratins, P-cadherin and vimentin are closely linked with tumorigenesis and metastasis. Cytokeratins are proteins of keratin-containing intermediate filaments in the intracytoplasmic cytoskeleton of epithelial tissue. Vimentin is the major intermediate filament protein of mesenchymal cells [125]. It regulates the interaction between cytoskeletal proteins (including cytokeratins) and cell adhesion molecules (such as P-cadherin), and thereby participates in cell adhesion, migration, invasion and cell signal transduction in tumor cells [125]. TP63 has been reported to play a tumor suppressive role in cancer metastasis [126].

The basal tumors, accounting for $10 \%$ to $25 \%$ of breast cancers [127, 128], have a worse prognosis than the other ER-PR-HER2- breast tumors. These two subtypes have distinct molecular and biological characteristics and differ in their response to neoadjuvant chemotherapy $[129,130]$. Thus, accurate identification of basal tumors from the ER-PR-HER2subtype is required for precise therapeutic strategy making. It has been suggested that tumors expressing more than one basal keratin are more likely to have a dysfunctional BRCA1 pathway [131]. Consistent with this, several other studies have also suggested the with basal carcinoma [13]. The basal markers used for in Table 1.

predictive value of basal keratins on BRCA1 mutation [132, 133]. Preclinical models of tumors with dysfunctional BRCA1 have been shown to be exclusively sensitive to cross-linking agents and inhibitors of the poly (ADP-ribose) polymerase [134], indicating the efficient therapeutic treatment of tumors of this class.

Though basal markers are primarily expressed among ER-PR-HER2- tumors and, particularly, the basal subtype, a small percentage of tumors with hormonal receptor positivity also exhibit basal marker expression (accounting 1\% to $18 \% \quad[\mathrm{ER}+\mid \mathrm{PR}+]$ tumors). This has led to the question that whether these patients belong to the luminal or basal tumors, and how the corresponding treatment should be given. It has been observed that $[\mathrm{ER}+\mid \mathrm{PR}+]$ tumors with basal marker expression exhibit a poorer prognosis than the conventional luminal tumors [16]. This may suggest a potential link between luminal B and basal breast tumors [19, 20]. Aside from this, basal markers are also reported to be present in a small proportion of HER2 positive tumors, which are less responsive to Herceptin treatment than the conventional HER2 positive tumors [135].

The poor prognosis of triple negative tumors is associated with the 'activating invasion and metastasis' hallmark. The ambiguities exhibited in tumor classification when basal markers are included suggest that breast tumors, regardless of which subtype they belong to, once harboring the 'activating invasion and metastasis' hallmark, exhibit either poorer prognosis (luminal tumors with basal markers) or drug resistance (HER2 positive tumors with basal markers).

Table 1. Different immunohistochemical marker combinations used to define the basal phenotype in various publications.

\begin{tabular}{|c|c|c|c|c|c|c|c|c|c|c|c|}
\hline \multirow{2}{*}{$\begin{array}{l}\text { Journal } \\
\text { article }\end{array}$} & \multicolumn{11}{|c|}{ Immunohistochemical marker } \\
\hline & $\overline{E R}$ & PR & HER2 & CK5/6 & CK14 & CK17 & CK8/18 & EGFR & Vimentin & P-cadherin & TP-63 \\
\hline $\begin{array}{l}\text { Carey et } \\
\text { al., } \\
2006[85]\end{array}$ & - & - & - & $+/-a$ & & & & $+/-\mathrm{a}$ & & & \\
\hline $\begin{array}{l}\text { Cheang et } \\
\text { al., } \\
2008[123]\end{array}$ & - & - & - & $+/-\mathrm{a}$ & & & & $+/-\mathrm{a}$ & & & \\
\hline $\begin{array}{l}\text { Rakha et } \\
\text { al., } \\
2009[184]\end{array}$ & - & - & - & $+/-\mathrm{a}$ & $+/-\mathrm{a}$ & $+/-\mathrm{a}$ & & $+/-\mathrm{a}$ & & & \\
\hline $\begin{array}{l}\text { Matos et } \\
\text { al., } \\
\text { 2005[89] }\end{array}$ & & & & + & & & & & & + & + \\
\hline $\begin{array}{l}\text { Nielsen et } \\
\text { al., } \\
2004[90]\end{array}$ & - & & - & $+/-\mathrm{a}$ & & & & $+/-\mathrm{a}$ & & & \\
\hline $\begin{array}{l}\text { Livasy et } \\
\text { al., } 2006 \\
{[124]}\end{array}$ & - & & - & + & & & + & + & + & & \\
\hline $\begin{array}{l}\text { Rakha et } \\
\text { al., } \\
\text { 2007[120] }\end{array}$ & & & & $+/-\mathrm{a}$ & $+/-\mathrm{a}$ & & & & & & \\
\hline $\begin{array}{l}\text { Fulford et } \\
\text { al., } \\
2006[13]\end{array}$ & & & & & + & & & & & & \\
\hline
\end{tabular}

a Positivity for at least one of the highlighted markers.

\section{EMT, Stem cell markers deteriorate ER-PR-HER2- tumors}

Epithelial to mesenchymal transition (EMT) is a reversible biological process that involves the transition from motile, multipolar or spindle-shaped mesenchymal cells to planar arrays of polarized cells called epithelia. EMT is a necessary process for metastasis. Markers of EMT primarily include VIM, SNAI1, SNAI2, TWIST1, TWIST2, ZEB1, ZEB2, CDH1, CLDN3 (claudin 3), CLDN4 (claudin 4), CLDN7 (claudin 7) [136, 137]. Molecules conventionally considered as stem cell markers include CD44, CD24, EpCAM, CD10, CD49, CD29, 
MUC1, THY1 and ALDH1A1 [138]. Availed by these markers, two groups of breast tumors, i.e., claudin-low and metaplastic breast cancer (MBC), could be further differentiated from ER-PR-HER2tumors. Both subtypes share many similarities regarding tumor characteristics, genomic aberrations as well as drug response and clinical outcome. They are characterized by low expression of GATA3-regulated and cell-cell adhesion genes, enriched for EMT markers, and displaying stem cell characteristics [139, 140]. It is claimed that claudin-low and MBCs may arise from a more primitive cell than the precursor to luminal or basal tumors, and define a novel chemo-resistant ER-PR-HER2- disease exhibiting a signature similar to that of breast tumor-initiating cells [139]. Though both breast tumor subtypes share a significant similarity regarding the EMT and stem cell markers, MBC breast cancer are distinct from claudin-low tumors by harboring PIK3CA, AKT or KRAS mutations [139]. For example, PIK3CA mutations are detected in $47.4 \%$ MBCs while no such mutation is found among claudin-low tumors [139]. Also important is that these subtypes are not mutually exclusive, with a small proportion overlapping [139].

Claudin-low tumors are ER-PR-HER2- tumors characterized by low gene expression of tight junction proteins claudins 3,4 and 7 as well as the calcium-dependent cell-cell adhesion glycoprotein CDH1 [141]. These tumors account for around $7 \%$ to $14 \%$ of breast tumors [141]. Molecular characterization of the claudin-low subtype reveals that they are enriched for EMT, stem cell-like and tumor initiating cell (TIC) genomic signatures, lack of common epithelial cell features and show low expression of luminal and proliferation-associated genes [141]. Though claudin-low cancers show some chemotherapy sensitivity, patients harboring these tumors suffer from poor overall survival [141].

MBC are aggressive ER-PR-HER2- tumors characterized by the co-existence of carcinoma with non-epithelial cellular elements [142], which accounts for $1 \%$ of breast cancer [143]. Tumors of this subtype are aggressive, chemoresistant, and associated with poor outcome [143]. MBC can be further classified into homogeneous spindle cell/sarcomatoid carcinoma, heterogeneous carcinosarcoma/carcinoma with sarcomatous differentiation (osseous, chondroid and rhabdod), and pure epithelial malignant tumors with metaplasia such as adenosquamous and pure squamous cell carcinomas [144]. Many pathologic and clinical parameters of MBCs are distinct from the other breast tumors. The incidence of nodal involvement among MBC ranges from $6 \%$ to $26 \%$, which is less frequent than typical breast tumors
[145-147]. These tumors tend to be present in an advanced stage, have a propensity for local recurrence and metastasize [143]. The recurrence rate for node-negative $\mathrm{MBC}$ ranges from $45 \%$ to $62 \%$ within 2 to 5 years from the initial diagnosis, which is much higher than the $17 \%$ to $20 \%$ recurrence rate for invasive ductal carcinoma of comparable tumor size [148]. As contrary to the basal tumors where neoadjuvant chemotherapy is typically associated with high pathological complete response rate, MBCs rarely benefit from such a treatment [149]. The stem cell features and frequent genomic aberrations activating the phosphatidylinositol 3-kinase (PI3K)/AKT signaling may suggest the source of MBC chemoresistance [139]. Accordingly, the PI3K/AKT pathway has been suggested as a therapeutic target in MBC [139]. Further, EMT and stem cell-like features are likely to contribute to the poor outcomes of these tumors and suggest novel therapeutic strategies [139].

Taken together, basal, EMT or stem cell markers, which represent the properties of the 'activating invasion and metastasis' hallmark, are more likely to be enriched in triple negative tumors. The more markers as such are enriched, the more aggressive the tumors are.

\section{Hallmark 3: Evading immune destruction}

\section{Immune response genes rescue ER-PR-HER2- tumors}

The interferon-rich subtype is recently identified from ER-PR-HER2- tumors, which is characterized by the over-expression of interferon-regulated genes [93, 150]. These tumors account for approximately $10 \%$ of breast tumor cases [93]. Among the interferon-regulated genes differentiating tumors of this subtype from the other ER-PR-HER2- cancers, STAT1 and SP110 are of the most importance, where STAT1 is the transcription factor mediating interferon-regulated gene expression [93], and SP110 is reported to have the prognostic value [150]. The relapse free survival of interferon-rich breast tumors is somewhere between the basal cancers (comparable with ER-PR-HER2+) and luminal A tumors, and is comparable with luminal B tumors [93], suggesting that the easier tumors fire the immune system the better outcome the patients show, and the more effective the appropriate therapeutic strategy might achieve.

Markers representing these three cancer hallmarks contribute to the current breast tumor classification. All conventional subtypes are summarized in Table 2. 


\section{Hallmark 4: Resisting cell death}

\section{BCL2 shows dual roles on tumor outcome prognosis and prediction}

The protein BCL2 is a suppressor of apoptosis, which has been verified in a variety of in vitro and in vivo experiments [151-153]. Its expression is shown to be inversely correlated with that of TP53, and its function could be substituted by TP53 mutation [154]. The prognostic value of BCL2 has been investigated by many studies $[155,156]$. It is found that moderate to strong BCL2 expression (abbreviated as BCL2+ tumors) is intensely associated with several favorable prognostic features, such as low mitotic count, low S-phase fraction size, low cathepsin D expression, high histological grade of differentiation, as well as lacking p53 expression and tumor necrosis [155]. Also, patients with BCL2+ tumors have a more favorable short-term but similar long-term breast cancer specific death as compared with those carrying BCL2- tumors [155]. Early studies report that BCL2 expression is associated with low-grade slowly proliferating ER+ breast tumors [157, 158], and the improved survival associated with such tumors is attributed to its correlation with ER status [159-161]. Several recent projects have suggested that BCL2 is a clinically valid and powerful prognostic marker for all types of early-stage breast cancer, independent of ER, HER2 and adjuvant therapy received [156, 162]; and its strong correlation with hormonal receptor might contribute to the superior survival observed for BCL2+ breast patients [156]. The predictive value of BCL2 is reported for ER-PR-HER2- breast tumors, with ER-PR-HER2-BCL2- patients found beneficial from anthracycline-based regimen [163]. These indicate that 'resisting cell death' is not a determinant factor for breast tumors to be aggressive but is important for triple negative tumors to develop anthracycline resistance.

\section{Hallmark 5: Genome instability and mutation}

\section{TP53 dysfunction increases tumor drug resistance}

The tumor suppressor TP53 plays a critical role in many cellular signaling controlling cell proliferation, survival, apoptosis and, most importantly, genomic integrity [154, 164]. It acts as a gatekeeper of the genome when cells experience stress conditions such as DNA damage, hypoxia and oncogene activation. Thus, TP53 deficiency may lead to uncontrolled proliferation of damaged cells as the genomic stability is hampered which leads to a faster mutation speed. Approximately $25 \%$ to $30 \%$ tumors have a mutation on TP53 [165-167], which has been reported as an important prognostic marker in breast cancer independent of tumor size, node status and hormone receptor content [164]. An interaction between TP53 and PR is revealed, where TP53-PRtumors are found associated with the worst prognosis among all breast cancers [164]. It has been shown that p53 mutation adversely affects breast cancer response to tamoxifen [164]. Increasing evidences have suggested that TP53 dysfunction is responsible for the development of anti-oestrogen resistance among ER+ tumors [168, 169], and ER-TP53- tumors may suffer from chemotherapy treatment failure $[165,170,171]$. These evidences altogether suggest that 'genome instability and mutation' contributes to tumor drug resistance regardless of which subtype it belongs to.

Table 2. Summary of the breast tumor molecular subtypes.

\begin{tabular}{|c|c|c|c|c|c|c|}
\hline Subtype & Alias & Biomarker status & Grade & Outcome & Additional features & Prevalence $^{\Delta}$ \\
\hline \multirow[t]{2}{*}{ Luminal } & ${\text { Luminal } \mathrm{A}^{*}}^{*}$ & [ER+|PR+]HER2-KI67- & $1 \mid 2$ & Good & $\begin{array}{l}\text { Luminal cytokeratin+, FOXA1+, ADH1B high; } \\
\text { cell-cell adhesion genes high }\end{array}$ & $23.7 \%{ }^{[9]}$ \\
\hline & Luminal $B^{*}$ & $\begin{array}{l}{[\text { ER+ }+ \text { PR+ }] \text { HER2-KI67+ }} \\
{[\text { ER+ }+ \text { PR+]HER2+KI67+ }}\end{array}$ & $2 \mid 3$ & $\begin{array}{l}\text { Intermediate } \\
\mid \text { Poor }\end{array}$ & $\begin{array}{l}\text { Luminal cytokeratin+; TP53-; FGFR1 and ZIC3 } \\
\text { amp; ADH1B low; cell-cell adhesion genes high }\end{array}$ & $\begin{array}{l}38.8 \%[9] \\
14 \%[9]\end{array}$ \\
\hline HER2 positive & $\begin{array}{l}\text { HER2 } \\
\text { over-expression }^{*}\end{array}$ & ER-PR-HER2+ & $2 \mid 3$ & Poor & TP53-; GRB7 high; cell-cell adhesion genes high & $11.2 \%[9]$ \\
\hline \multirow[t]{4}{*}{ Triple negative } & Basal $^{*}$ & ER-PR-HER2-, basal marker+ & 3 & Poor & $\begin{array}{l}\text { BRCA1-, TP53-; CDKN2A high; RB1 low; FGFR2 } \\
\text { amp; cell-cell adhesion genes high }\end{array}$ & $\begin{array}{l}10-25 \%[1 \quad 12.3 \%[9] \\
28]\end{array}$ \\
\hline & Claudin-low & $\begin{array}{l}\text { ER-PR-HER2-, EMT marker+, } \\
\text { Stem-cell marker+, claudin- }\end{array}$ & 3 & Poor & $\begin{array}{l}\text { GATA3-regulated genes, cell-cell adhesion genes } \\
\text { low; CDH1 low; Claudins low }\end{array}$ & $\begin{array}{l}7-14 \%[141 \\
1\end{array}$ \\
\hline & $\begin{array}{l}\text { Metaplastic breast } \\
\text { cancer (MBC) }\end{array}$ & $\begin{array}{l}\text { ER-PR-HER2-, EMT marker+, } \\
\text { Stem-cell marker+ }\end{array}$ & 3 & Poor & $\begin{array}{l}\text { GATA3-regulated genes, cell-cell adhesion genes } \\
\text { low; PIK3CA-, AKT- or KRAS- }\end{array}$ & $1 \%[143]$ \\
\hline & Interferon-rich & $\begin{array}{l}\text { ER-PR-HER2-, interferon } \\
\text { regulated genes+ }\end{array}$ & 3 & Intermediate & STAT1, SP110 high & $\sim 10 \%[93]$ \\
\hline $\begin{array}{l}\text { Molecular } \\
\text { apocrine cancer } \\
\text { (MAC) }\end{array}$ & $\begin{array}{l}\text { Molecular apocrine } \\
\text { cancer (MAC) }\end{array}$ & ER-PR-AR+ & $2 \mid 3$ & Poor & KI67+ & $13.2 \%[98]$ \\
\hline
\end{tabular}




\section{Hallmark 6: Deregulating cellular energetics}

\section{VRD provides novel view on breast tumor classification}

Higher level of circulating vitamin D metabolites is shown to be associated with decreased breast cancer risk [172-175], and the statues of vitamin D receptor (VRD), $A R$ and ER are known to be correlated with tumor differentiation state [176]. Santagata et al. [176] have proposed a novel breast tumor classification method jointly assessing the statues of these three receptors, according to which breast carcinomas could be quantitatively classified into 4 categories, i.e., HR3 (ER+AR+VDR+), HR2 $(\mathrm{ER}+\mathrm{AR}+, \mathrm{AR}+\mathrm{VDR}+, \mathrm{ER}+\mathrm{VDR}+), \mathrm{HR} 1(\mathrm{ER}+, \mathrm{VDR}+$, $\mathrm{AR}+$ ), and HR0 (ER-AR-VDR-). This classification differs from the conventional ER-PR-HER2 based grouping. For example, in the samples collected by Santagata [176]: among ER+ tumors, $75.1 \%$ are HR3, 23.4\% are HR2, $1.5 \%$ are HR1; for HER2+tumors, $29.4 \%$ are HR3, $43.5 \%$ are HR2, $22 \%$ are HR1 and 5.1\% are HR0; and of TNP tumors, $36.5 \%$ are HR0, $44.6 \%$ are HR1 and $18.6 \%$ are HR2. Tumors classified using these markers have different clinical outcomes, with HR3 tumors being associated with the best survival and HR1 and HR0 tumors the most aggressive [176]. An intriguing implication of this novel classification is targeting VDR and AR in conjunction with ER for patients receiving hormone therapy, which is potentially a more efficient therapeutic strategy [176, 177].

\section{Discussion}

Among ER+ tumors, the traditional classification of breast tumors into four categories using ER, PR, and HER2 has been frequently challenged by samples with exceptional clinical associations. The role of KI67 in characterizing these subtypes has been gaining attention, suggesting the prominent role of the 'sustaining proliferative signaling' hallmark played in $[\mathrm{ER}+\mid \mathrm{PR}+]$ tumors.

Many ER-PR-HER2+ tumors overlap with ER-PR-AR+ (MAC), which are both associated with poor prognosis and tumors of grade 2 or 3 . These seemingly imply a similar role played by HER2 and AR which, however, differ in that HER2 is a growth factor receptor and $\mathrm{AR}$ is a hormonal receptor involved in the control of male characteristics. Note that MAC tumors are also characteristic of KI67+ (Table 2), and KI67 is frequently recognized together with hormonal receptor positive tumors (above paragraph) and indicative of proliferation. Thus, the progressive nature of hormonal receptor (ER, PR, or
AR) positive subtypes may be governed by 'sustaining proliferative signaling'.

ER-PR-HER2- tumors are notorious for their poor diagnosis, lack of efficient therapeutic treatments and high heterogeneity. It has been suggested that ER status is shifted from positive to negative in up to $70 \%$ of tumors showing acquired resistance and as the disease progressed from primary to metastatic state [178-183]. This, on one hand, shows the more aggressive nature of ER- tumors than ER+ ones in general and, on the other hand, suggests a switch on cancer hallmarks during carcinogenesis as well as its connection with ER status. Basal markers, EMT markers, claudins, immune response genes have been revealed to identify basal $[85,89,90,116-119], \mathrm{MBC}$ [139], claudin-low [139] and interferon-rich cancers $[93,150]$ from tumors of this kind. CK are the most widely used basal markers, which contribute to cell-cell adhesion, and claudins are a family of proteins that are the most important components of the tight junctions. These suggest that 'activating invasion and metastasis' drives the differences among basal tumors, $\mathrm{MBC}$, and claudin-low cancers, despite the different markers used for their identification. Indeed, as shown by Table 2, these ER-PR-HER2tumors are all associated with poor clinical outcome and of grade 3 cancers. Also, recall that MBC and claudin-low tumors share many similarities regarding their, e.g., genomic aberrations and drug response, in addition to clinical outcome. The interferon-rich subtype, as indicated by its name, may differentiate itself from the other ER-PR-HER2- tumors by 'evading immune destruction'.

Novel biomarkers keep emerging, with more and more cancer hallmarks unveiled critical in deciphering breast cancer heterogeneity. For example, BCL2 is related to 'resisting cell death', TP53 represents the hallmark of 'genome instability and mutation', and VRD is associated with the level of circulating vitamin $\mathrm{D}$ metabolites and thus the 'deregulating cellular energetics' hallmark.

\section{Concluding Remarks}

As a tumor consisting of a collection of different diseases, various biomarkers have been identified to categorize them into different subtypes. Despite the novel subtypes being kept identified, the dominant cancer hallmarks driving such heterogeneity stay invariant. In summary, the extent to which cells having 'sustaining proliferative signaling' is of particular importance in breast tumor classification, especially among $\mathrm{HR}$ positive tumors such as [ER+ $\mid$ PR+]HER2-, $[$ ER+ $\mid$ PR+]HER2+, and MAC.

In tumors lacking hormone receptors, i.e., ER-PR-HER2-, other cancer hallmarks take the role 
and are often associated with more aggressive properties. Among these, 'activating invasion and metastasis' is of the most importance, based on which basal, claudin-low and MBC are differentiated from ER-PR-HER2- tumors. Also important for tumors of this kind is the emerging hallmark 'evading immune destruction', according to which a novel subtype, interferon-rich cancer, is identified. These ER-PR-HER2- subtypes, though distinct, are not mutually exclusive.

Other hallmarks, such as 'resisting cell death', 'genome instability and mutation' and 'deregulating cellular energetics' help to refine tumor classification and contribute, in particular, on predictive value.

With the arrival of the times of precision medicine, precise molecular characterization of the heterogeneity of complex diseases such as breast cancer has become of particular importance. Though the basic receptors (ER, PR, HER2) classifying breast tumors stay the same, novel biomarkers and approaches in subtyping of such tumors have been kept reported. This, in turn, has led us to an overwhelming realm of breast tumor subtypes that are not mutually exclusive, complicating our understandings towards breast cancer classification. This, on one hand, is due to the inconsistent criteria used for breast tumor identification and, on the other hand, suggests that we may have lost the global view on unveiling breast tumor heterogeneity. Here, by reviewing the current biomarkers and their associations with cancer hallmarks, we claim that 'the divergent outcome observed from cancer patients are driven by cancer hallmarks but not biomarkers; thus, biomarkers may vary among studies but cancer hallmarks driving such differences should stay invariant'.

Among the 10 cancer hallmarks, 6 have been covered by the current studies on breast tumor classification. This suggests that further efforts in this area should be inclined to the rest four hallmarks, i.e., 'evading growth suppressors', 'enabling replicative immortality', 'inducing angiogenesis' and 'tumor-promoting inflammation', assuming that all cancer hallmarks contribute to breast tumor heterogeneity.

\section{Abbreviations}

IHC: immunohistochemistry; ER: estrogen receptor; PR: progesterone receptor; HER2: human epidermal growth factor receptor 2; HR: hormonal receptors; AR: androgen receptor; [ER+ $\mid \mathrm{PR}+]$ HER2-: tumors with either ER or PR positivity, and HER2 negativity; [ER+|PR+]HER2+: tumors with either ER or PR positivity, and HER2 positivity; ER-PR-HER2+: tumors with ER and PR negativity, and HER2 positivity, also named HER2 positive; ER-PR-HER2-: tumors with ER, PR, HER2 negativity, also named triple negative; ER-PR- tumors: tumors with both ER and PR negativity; $[\mathrm{ER}+\mid \mathrm{PR}+]$ cancers: tumors with either ER or PR positivity; MAC: ER-PR-AR+, also named molecular apocrine; GEP: gene expression profiling; EMT: epithelial to mesenchymal transition; CMF: cyclophosphamide, methotrexate, 5-fluorouracil; TIC: tumor initiating cell; TOP2A: Topoisomerase II alpha; CK: cytokeratins; EGFR: epidermal growth factor receptor; VRD: vitamin D receptor; VIM: vimentin; MBC: metaplastic breast cancers; PI3K: phosphatidylinositol 3-kinase

\section{Acknowledgements}

This work was supported by the National Natural Science Foundation of China (grant number 31471251) and the Jiangnan University Research Foundation for Young Scientists (grant number 5922050205150370).

\section{Competing Interests}

The authors have declared that no competing interest exists.

\section{References}

1. Spitale A, Mazzola P, Soldini D, Mazzucchelli L, Bordoni A. Breast cancer classification according to immunohistochemical markers: clinicopathologic features and short-term survival analysis in a population-based study from the South of Switzerland. Annals of oncology : official journal of the European Society for Medical Oncology / ESMO. 2009; 20: 628-35.

2. Tang P, Wang J, Bourne P. Molecular classifications of breast carcinoma with similar terminology and different definitions: are they the same? Human pathology. 2008; 39: 506-13.

3. Desmedt C, Sotiriou C, Piccart-Gebhart MJ. Development and validation of gene expression profile signatures in early-stage breast cancer. Cancer investigation. 2009; 27: 1-10.

4. Iwamoto T, Pusztai L. Predicting prognosis of breast cancer with gene signatures: are we lost in a sea of data? Genome medicine. 2010; 2: 81.

5. Reis-Filho JS, Weigelt B, Fumagalli D, Sotiriou C. Molecular profiling: moving away from tumor philately. Science translational medicine. 2010; 2: 47ps3.

6. Sotiriou C, Pusztai L. Gene-expression signatures in breast cancer. The New England journal of medicine. 2009; 360: 790-800.

7. Weigelt B, Baehner FL, Reis-Filho JS. The contribution of gene expression profiling to breast cancer classification, prognostication and prediction: a retrospective of the last decade. The Journal of pathology. 2010; 220: 263-80.

8. Blows FM, Driver KE, Schmidt MK, Broeks A, van Leeuwen FE, Wesseling J, et al. Subtyping of breast cancer by immunohistochemistry to investigate a relationship between subtype and short and long term survival: a collaborative analysis of data for 10,159 cases from 12 studies. PLoS Med. 2010; 7: e1000279.

9. Cheang MC, Chia SK, Voduc D, Gao D, Leung S, Snider J, et al. Ki67 index, HER2 status, and prognosis of patients with luminal B breast cancer. Journal of the National Cancer Institute. 2009; 101: 736-50.

10. Vallejos CS, Gomez HL, Cruz WR, Pinto JA, Dyer RR, Velarde R, et al. Breast Cancer Classification According to Immunohistochemistry Markers: Subtypes and Association With Clinicopathologic Variables in a Peruvian Hospital Database. Clinical breast cancer. 2010; 10: 294-300.

11. Hanahan D, Weinberg RA. The hallmarks of cancer. cell. 2000; 100: 57-70.

12. Hanahan D, Weinberg RA. Hallmarks of Cancer: The Next Generation. Cell. 2011; 144: 646-74.

13. Fulford LG, Easton DF, Reis-Filho JS, Sofronis A, Gillett CE, Lakhani SR, et al. Specific morphological features predictive for the basal phenotype in grade 3 invasive ductal carcinoma of breast. Histopathology. 2006; 49: 22-34.

14. Moon RC, Pike M, Siiteri P, Welsch C. Influence of pregnancy and lactation on experimental mammary carcinogenesis. Banbury report. 1981; 8: 353-64.

15. Lippman M, Bolan G, Huff K. The effects of gluoocorticoids and progesterone on hormone responsive human breast cancer in long term tissue culture. Cancer research. 1976: 3614602-4609. 
16. Rakha EA, Reis-Filho JS, Ellis IO. Combinatorial biomarker expression in breast cancer. Breast cancer research and treatment. 2010; 120: 293-308.

17. Dai X, Chen A, Bai Z. Integrative investigation on breast cancer in ER, PR and HER2-defined subgroups using mRNA and miRNA expression profiling. Scientific reports. 2014; 4: 6566

18. Perou CM, Sørlie T, Eisen MB, van de Rijn M, Jeffrey SS, Rees CA, et al. Molecular portraits of human breast tumours. Nature. 2000; 406: 747-52.

19. Sørlie T, Perou CM, Tibshirani R, Aas T, Geisler S, Johnsen H, et al. Gene expression patterns of breast carcinomas distinguish tumor subclasses with clinical implications. P Natl Acad Sci USA. 2001; 98: 10869-74.

20. Sørlie T, Tibshirani R, Parker J, Hastie T, Marron JS, Nobel A, et al. Repeated observation of breast tumor subtypes in independent gene expression data sets. P Natl Acad Sci USA. 2003; 100: 8418-23.

21. Sotiriou C, Neo SY, McShane LM, Korn EL, Long PM, Jazaeri A, et al. Breast cancer classification and prognosis based on gene expression profiles from a population-based study. Proceedings of the National Academy of Sciences of the United States of America. 2003; 100: 10393-8.

22. Ellis I, Pinder S, Bobrow L, Buley I, Coyne J, Going J, et al. Pathology reporting of breast disease. NHS publication. 2005

23. Anderson WF, Chatterjee N, Ershler WB, Brawley OW. Estrogen receptor breast cancer phenotypes in the Surveillance, Epidemiology, and End Results database. Breast cancer research and treatment. 2002; 76: 27-36.

24. Dunnwald LK, Rossing MA, Li CI. Hormone receptor status, tumor characteristics, and prognosis: a prospective cohort of breast cancer patients. Breast cancer research : BCR. 2007; 9: R6.

25. Putti TC, El-Rehim DMA, Rakha EA, Paish CE, Lee AH, Pinder SE, et al. Estrogen receptor-negative breast carcinomas: a review of morphology and mmunophenotypical analysis. Modern pathology : an official journal of the United States and Canadian Academy of Pathology, Inc. 2005; 18: 26-35.

26. Group EBCTC. Effects of chemotherapy and hormonal therapy for early breast cancer on recurrence and 15-year survival: an overview of the randomised trials. The Lancet. 2005; 365: 1687-717.

27. Badve S, Nakshatri H. Oestrogen-receptor-positive breast cancer: towards bridging histopathological and molecular classifications. Journal of clinical pathology. 2009; 62: 6-12

28. Oh DS, Troester MA, Usary J, Hu Z, He X, Fan C, et al. Estrogen-regulated genes predict survival in hormone receptor-positive breast cancers. Journal of clinical oncology : official journal of the American Society of Clinical Oncology. 2006; 24: 1656-64.

29. Group EBCTC. Tamoxifen for early breast cancer: an overview of the randomised trials. The Lancet. 1998; 351: 1451-67.

30. Esserman LJ, Ozanne EM, Dowsett M, Slingerland JM. Tamoxifen may prevent both ER+ and ER- breast cancers and select for ER- carcinogenesis: an alternative hypothesis. Breast cancer research : BCR. 2005; 7: R1153-8.

31. Dowsett M, Houghton J, Iden C, Salter J, Farndon I, A'Hern R, et al. Benefit from adjuvant tamoxifen therapy in primary breast cancer patients according oestrogen receptor, progesterone receptor, EGF receptor and HER2 status. Annals of oncology : official journal of the European Society for Medical Oncology / ESMO. 2006; 17: 818-26.

32. Farmer P, Bonnefoi H, Becette V, Tubiana-Hulin M, Fumoleau P, Larsimont D, et al. Identification of molecular apocrine breast tumours by microarray analysis. Oncogene. 2005; 24: 4660-71.

33. Chin K, DeVries S, Fridlyand J, Spellman PT, Roydasgupta R, Kuo WL, et al. Genomic and transcriptional aberrations linked to breast cancer pathophysiologies. Cancer cell. 2006; 10: 529-41.

34. Natrajan R, Lambros MB, Rodriguez-Pinilla SM, Moreno-Bueno G, Tan DS, Marchio $C$, et al. Tiling path genomic profiling of grade 3 invasive ductal breast cancers. Clinical cancer research : an official journal of the American Association for Cancer Research. 2009; 15: 2711-22.

35. Natrajan R, Weigelt B, Mackay A, Geyer FC, Grigoriadis A, Tan DS, et al. An integrative genomic and transcriptomic analysis reveals molecular pathways and networks regulated by copy number aberrations in basal-like, HER2 and luminal cancers. Breast cancer research and treatment. 2010; 121: 575-89.

36. Nikolsky Y, Sviridov E, Yao J, Dosymbekov D, Ustyansky V, Kaznacheev V, et al. Genome-wide functional synergy between amplified and mutated genes in human breast cancer. Cancer research. 2008; 68: 9532-40.

37. Horwitz KB, Koseki Y, McGuire WL. Estrogen control of progesterone receptor in human breast cancer: role of estradiol and antiestrogen. Endocrinology. 1978; 103: 1742-51.

38. Horwitz KB, McGuire WL. Specific progesterone receptors in human breast cancer. Steroids. 1975; 25: 497-505.

39. Lanari C, Lamb CA, Fabris VT, Helguero LA, Soldati R, Bottino MC, et al. The MPA mouse breast cancer model: evidence for a role of progesterone receptors in breast cancer. Endocrine-related cancer. 2009; 16: 333-50.

40. Walker RA. Immunohistochemical markers as predictive tools for breast cancer. Journal of clinical pathology. 2008; 61: 689-96.

41. Colomer R, Beltran M, Dorcas J, Cortes-Funes H, Hornedo J, Valentin V, et al. It is not time to stop progesterone receptor testing in breast cancer. Journal of clinical oncology : official journal of the American Society of Clinical Oncology. 2005; 23: 3868-9; author reply 9-70.

42. Stendahl M, Ryden L, Nordenskjold B, Jonsson PE, Landberg G, Jirstrom K. High progesterone receptor expression correlates to the effect of adjuvant tamoxifen in premenopausal breast cancer patients. Clinical cancer research : an official journal of the American Association for Cancer Research. 2006; 12: $4614-8$.
43. Ryden L, Jonsson PE, Chebil G, Dufmats M, Ferno M, Jirstrom K, et al. Two years of adjuvant tamoxifen in premenopausal patients with breast cancer: a randomised, controlled trial with long-term follow-up. European journal of cancer. 2005; 41: 256-64.

44. Ravdin PM, Green S, Dorr TM, McGuire WL, Fabian C, Pugh RP, et al. Prognostic significance of progesterone receptor levels in estrogen receptor-positive patients with metastatic breast cancer treated with tamoxifen: results of a prospective Southwest Oncology Group study. Journal of clinical oncology : official journal of the American Society of Clinical Oncology. 1992; 10: 1284-91.

45. Elledge RM, Green S, Pugh R, Allred DC, Clark GM, Hill J, et al. Estrogen receptor (ER) and progesterone receptor (PgR), by ligand-binding assay compared with ER, PgR and pS2, by immuno-histochemistry in predicting response to tamoxifen in metastatic breast cancer: a Southwest Oncology Group Study. International journal of cancer Journal international du cancer. 2000; 89: 111-7.

46. Regan MM, Viale G, Mastropasqua MG, Maiorano E, Golouh R, Carbone A, et al. Re-evaluating adjuvant breast cancer trials: assessing hormone receptor status by immunohistochemical versus extraction assays. Journal of the National Cancer Institute. 2006; 98: 1571-81.

47. Olivotto IA, Truong PT, Speers CH, Bernstein V, Allan SJ, Kelly SJ, et al. Time to stop progesterone receptor testing in breast cancer management. Journal of clinical oncology : official journal of the American Society of Clinical Oncology. 2004; 22: 1769-70.

48. Viale G, Regan MM, Maiorano E, Mastropasqua MG, Dell'Orto P, Rasmussen $\mathrm{BB}$, et al. Prognostic and predictive value of centrally reviewed expression of estrogen and progesterone receptors in a randomized trial comparing letrozole and tamoxifen adjuvant therapy for postmenopausal early breast cancer: BIG 1-98. Journal of clinical oncology : official journal of the American Society of Clinical Oncology. 2007; 25: 3846-52.

49. Yu KD, Di GH, Wu J, Lu JS, Shen KW, Liu GY, et al. Breast cancer patients with estrogen receptor-negative/progesterone receptor-positive tumors: being younger and getting less benefit from adjuvant tamoxifen treatment. Journal of cancer research and clinical oncology. 2008; 134: 1347-54.

50. Allred DC. Commentary: hormone receptor testing in breast cancer: a distress signal from Canada. The oncologist. 2008; 13: 1134-6.

51. Rhodes A, Jasani B. The oestrogen receptor-negative/progesterone receptor-positive breast tumour: a biological entity or a technical artefact? Journal of clinical pathology. 2009; 62: 95-6.

52. de Cremoux P, Tran-Perennou C, Elie C, Boudou E, Barbaroux C, Poupon MF, et al. Quantitation of estradiol receptors alpha and beta and progesterone receptors in human breast tumors by real-time reverse transcription-polymerase chain reaction: Correlation with protein assays. Biochemical pharmacology. 2002; 64: 507-15

53. Rakha EA, El-Sayed ME, Green AR, Paish EC, Powe DG, Gee J, et al. Biologic and clinical characteristics of breast cancer with single hormone receptor positive phenotype. Journal of clinical oncology : official journal of the American Society of Clinical Oncology. 2007; 25: 4772-8.

54. Bardou VJ, Arpino G, Elledge RM, Osborne CK, Clark GM. Progesterone receptor status significantly improves outcome prediction over estrogen receptor status alone for adjuvant endocrine therapy in two large breast cancer databases. Journal of clinical oncology: official journal of the American Society of Clinical Oncology. 2003; 21: 1973-9.

55. Arpino G, Weiss H, Lee AV, Schiff R, De Placido S, Osborne CK, et al. Estrogen receptor-positive, progesterone receptor-negative breast cancer: association with growth factor receptor expression and tamoxifen resistance. Journal of the National Cancer Institute. 2005; 97: 1254-61.

56. Ferno M, Stal O, Baldetorp B, Hatschek T, Kallstrom AC, Malmstrom P, et al. Results of two or five years of adjuvant tamoxifen correlated to steroid receptor and S-phase levels. South Sweden Breast Cancer Group, and South-East Sweden Breast Cancer Group. Breast cancer research and treatment. 2000; 59: 69-76

57. Anderson WF, Chu KC, Chatterjee N, Brawley O, Brinton LA. Tumor variants by hormone receptor expression in white patients with node-negative breast cancer from the surveillance, epidemiology, and end results database. Journal of clinical oncology : official journal of the American Society of Clinical Oncology. 2001; 19: 18-27.

58. Kinne DW, Butler JA, Kimmel M, Flehinger BJ, Menendez-Botet C, Schwartz M. Estrogen receptor protein of breast cancer in patients with positive nodes. High recurrence rates in the postmenopausal estrogen receptor-negative group. Archives of surgery. 1987; 122: 1303-6.

59. Parl FF, Schmidt BP, Dupont WD, Wagner RK. Prognostic significance of estrogen receptor status in breast cancer in relation to tumor stage, axillary node metastasis, and histopathologic grading. Cancer. 1984; 54: 2237-42.

60. Weigelt B, Reis-Filho JS. Histological and molecular types of breast cancer: is there a unifying taxonomy? Nature reviews Clinical oncology. 2009; 6: 718-30.

61. Osborne CK, Yochmowitz MG, Knight WA, 3rd, McGuire WL. The value of estrogen and progesterone receptors in the treatment of breast cancer. Cancer. 1980; 46: 2884-8

62. Sundblad AS, Caprarulo L. [Immunohistochemical characteristics of mammary carcinomas with estrogen-negative and progesterone-positive receptors]. Medicina. 1996; 56: 683-9.

63. Blenkiron C, Goldstein LD, Thorne NP, Spiteri I, Chin SF, Dunning MJ, et al. MicroRNA expression profiling of human breast cancer identifies new markers of tumor subtype. Genome Biology. 2007; 8 
64. Goldhirsch A, Wood WC, Gelber RD, Coates AS, Thurlimann B, Senn HJ, et al. Progress and promise: highlights of the international expert consensus on the primary therapy of early breast cancer 2007. Annals of oncology : official journal of the European Society for Medical Oncology / ESMO. 2007; 18: 1133-44.

65. Dowsett M, Cuzick J, Wale C, Howell T, Houghton J, Baum M. Retrospective analysis of time to recurrence in the ATAC trial according to hormone receptor status: an hypothesis-generating study. Journal of clinical oncology : official journal of the American Society of Clinical Oncology. 2005; 23: 7512-7.

66. Slamon DJ, Clark GM, Wong SG, Levin WJ, Ullrich A, McGuire WL. Human breast cancer: correlation of relapse and survival with amplification of the HER-2/neu oncogene. Science. 1987; 235: 177-82.

67. Wolff AC, Hammond ME, Schwartz JN, Hagerty KL, Allred DC, Cote RJ, et al. American Society of Clinical Oncology/College of American Pathologists guideline recommendations for human epidermal growth factor receptor 2 testing in breast cancer. Journal of clinical oncology : official journal of the American Society of Clinical Oncology. 2007; 25: 118-45.

68. Bartlett J, Mallon E, Cooke T. The clinical evaluation of HER-2 status: which test to use? The Journal of pathology. 2003; 199: 411-7.

69. Chia S, Norris B, Speers C, Cheang M, Gilks B, Gown AM, et al. Human epidermal growth factor receptor 2 overexpression as a prognostic factor in a large tissue microarray series of node-negative breast cancers. Journal of clinical oncology : official journal of the American Society of Clinical Oncology. 2008; 26: 5697-704.

70. Dandachi N, Dietze O, Hauser-Kronberger C. Chromogenic in situ hybridization: a novel approach to a practical and sensitive method for the detection of HER2 oncogene in archival human breast carcinoma. Laboratory investigation; a journal of technical methods and pathology. 2002; 82: 1007-14.

71. Quenel N, Wafflart J, Bonichon F, de Mascarel I, Trojani M, Durand M, et al. The prognostic value of c-erbB2 in primary breast carcinomas: a study on 942 cases. Breast cancer research and treatment. 1995; 35: 283-91.

72. Piccart-Gebhart MJ, Procter M, Leyland-Jones B, Goldhirsch A, Untch M, Smith I, et al. Trastuzumab after adjuvant chemotherapy in HER2-positive breast cancer. The New England journal of medicine. 2005; 353: 1659-72.

73. Slamon DJL, Shak S, et al. Use of chemotherapy plus a monoclonal antibody against HER2 for metastatic breast cancer that overexpresses HER2. The New England journal of medicine. 2001; 344: 783-92

74. Pritchard KI, Messersmith $\mathrm{H}$, Elavathil L, Trudeau M, O'Malley F, Dhesy-Thind B. HER-2 and topoisomerase II as predictors of response to chemotherapy. Journal of clinical oncology : official journal of the American Society of Clinical Oncology. 2008; 26: 736-44.

75. Gianni L, Norton L, Wolmark N, Suter TM, Bonadonna G, Hortobagyi GN. Role of anthracyclines in the treatment of early breast cancer. Journal of clinical oncology : official journal of the American Society of Clinical Oncology 2009; 27: 4798-808

76. Tubbs R, Barlow WE, Budd GT, Swain E, Porter P, Gown A, et al. Outcome of patients with early-stage breast cancer treated with doxorubicin-based adjuvant chemotherapy as a function of HER2 and TOP2A status. Journal of clinical oncology : official journal of the American Society of Clinical Oncology. 2009; 27: 3881-6.

77. Pritchard KI, Shepherd LE, O'Malley FP, Andrulis IL, Tu D, Bramwell VH, et al. HER2 and responsiveness of breast cancer to adjuvant chemotherapy. The New England journal of medicine. 2006; 354: 2103-11.

78. Wood WC, Budman DR, Korzun AH, Cooper MR, Younger J, Hart RD, et al. Dose and dose intensity of adjuvant chemotherapy for stage II, node-positive breast carcinoma. The New England journal of medicine. 1994; 330: 1253-9.

79. Thor AD, Berry DA, Budman DR, Muss HB, Kute T, Henderson IC, et al. erbB-2, p53, and efficacy of adjuvant therapy in lymph node-positive breast cancer. Journal of the National Cancer Institute. 1998; 90: 1346-60.

80. Konecny GE, Thomssen C, Luck HJ, Untch M, Wang HJ, Kuhn W, et al. Her-2/neu gene amplification and response to paclitaxel in patients with metastatic breast cancer. Journal of the National Cancer Institute. 2004; 96: 1141-51.

81. Hayes DF, Thor AD, Dressler LG, Weaver D, Edgerton S, Cowan D, et al. HER2 and response to paclitaxel in node-positive breast cancer. The New England journal of medicine. 2007; 357: 1496-506.

82. Konecny G, Pauletti G, Pegram M, Untch M, Dandekar S, Aguilar Z, et al. Quantitative association between HER-2/neu and steroid hormone receptors in hormone receptor-positive primary breast cancer. Journal of the National Cancer Institute. 2003; 95: 142-53

83. Ellis MJ, Coop A, Singh B, Mauriac L, Llombert-Cussac A, Janicke F, et al. Letrozole is more effective neoadjuvant endocrine therapy than tamoxifen for ErbB-1- and/or ErbB-2-positive, estrogen receptor-positive primary breast cancer: evidence from a phase III randomized trial. Journal of clinical oncology : official journal of the American Society of Clinical Oncology. 2001; 19: 3808-16.

84. Rasmussen BB, Regan MM, Lykkesfeldt AE, Dell'Orto P, Del Curto B, Henriksen $\mathrm{KL}$, et al. Adjuvant letrozole versus tamoxifen according to centrally-assessed ERBB2 status for postmenopausal women with endocrine-responsive early breast cancer: supplementary results from the BIG 1-98 randomised trial. The Lancet Oncology. 2008; 9: 23-8.

85. Carey LA, Perou CM, Livasy CA, Dressler LG, Cowan D, Conway K, et al. Race, breast cancer subtypes, and survival in the Carolina Breast Cancer Study. Jama. 2006; 295: 2492-502.
86. Ihemelandu CU, Leffall LD, Jr., Dewitty RL, Naab TJ, Mezghebe HM, Makambi $\mathrm{KH}$, et al. Molecular breast cancer subtypes in premenopausal African-American women, tumor biologic factors and clinical outcome. Annals of surgical oncology. 2007; 14: 2994-3003.

87. Sørlie T. Molecular portraits of breast cancer: tumour subtypes as distinct disease entities. European journal of cancer. 2004; 40: 2667-75.

88. Wirapati P, Sotiriou C, Kunkel S, Farmer P, Pradervand S, Haibe-Kains B, et al. Meta-analysis of gene expression profiles in breast cancer: toward a unified understanding of breast cancer subtyping and prognosis signatures. Breast cancer research : BCR. 2008; 10: R65.

89. Matos I, Dufloth R, Alvarenga M, Zeferino LC, Schmitt F. p63, cytokeratin 5, and P-cadherin: three molecular markers to distinguish basal phenotype in breast carcinomas. Virchows Archiv : an international journal of pathology. 2005; 447: 688-94.

90. Nielsen TO, Hsu FD, Jensen K, Cheang M, Karaca G, Hu Z, et al. Immunohistochemical and clinical characterization of the basal-like subtype of invasive breast carcinoma. Clinical cancer research : an official journal of the American Association for Cancer Research. 2004; 10: 5367-74.

91. Network CGA. Comprehensive molecular portraits of human breast tumours. Nature. 2012; 490: 61-70.

92. Cuzick J, Dowsett M, Wale C, Salter J, Quinn E, Zabaglo L, et al. Prognostic Value of a Combined ER, PgR, Ki67, HER2 Immunohistochemical (IHC4) Score and Comparison with the GHI Recurrence Score-Results from TransATAC. Cancer research. 2009; 69: 74

93. $\mathrm{Hu}$ Z, Fan C, Oh DS, Marron JS, He X, Qaqish BF, et al. The molecular portraits of breast tumors are conserved across microarray platforms. BMC genomics. 2006; 7: 96.

94. Nikas JB, Low WC, Burgio PA. Prognosis of treatment response (pathological complete response) in breast cancer. Biomarker insights. 2012; 7: 59-70.

95. Lehmann BD, Bauer JA, Chen X, Sanders ME, Chakravarthy AB, Shyr Y, et al. Identification of human triple-negative breast cancer subtypes and preclinical models for selection of targeted therapies. The Journal of clinical investigation. 2011; 121: 2750-67.

96. Hu R, Dawood S, Holmes MD, Collins LC, Schnitt SJ, Cole K, et al. Androgen receptor expression and breast cancer survival in postmenopausal women. Clinical cancer research : an official journal of the American Association for Cancer Research. 2011; 17: 1867-74.

97. Ogawa Y, Hai E, Matsumoto K, Ikeda K, Tokunaga S, Nagahara H, et al. Androgen receptor expression in breast cancer: relationship with clinicopathological factors and biomarkers. International journal of clinical oncology. 2008; 13: 431-5.

98. Lakis S, Kotoula V, Eleftheraki AG, Batistatou A, Bobos M, Koletsa T, et al. The androgen receptor as a surrogate marker for molecular apocrine breast cancer subtyping. Breast. 2014; 23: 234-43.

99. Van Diest P, Van Der Wall E, Baak J. Prognostic value of proliferation in invasive breast cancer: a review. Journal of clinical pathology. 2004; 57: 675-81.

100. Veronese SM, Gambacorta M, Gottardi O, Scanzi F, Ferrari M, Lampertico P. Proliferation index as a prognostic marker in breast cancer. Cancer. 1993; 71: 3926-31.

101. Colozza M, Azambuja E, Cardoso F, Sotiriou C, Larsimont D, Piccart MJ. Proliferative markers as prognostic and predictive tools in early breast cancer: where are we now? Annals of Oncology. 2005; 16: 1723-39.

102. Vincent-Salomon A, Rousseau A, Jouve M, Beuzeboc P, Sigal-Zafrani B, Freneaux $\mathrm{P}$, et al. Proliferation markers predictive of the pathological response and disease outcome of patients with breast carcinomas treated by anthracycline-based preoperative chemotherapy. European journal of cancer. 2004; 40: 1502-8

103. Miglietta L, Vanella P, Canobbio L, Parodi MA, Guglielmini P, Boccardo F. Clinical and pathological response to primary chemotherapy in patients with locally advanced breast cancer grouped according to hormonal receptors, Her2 status, grading and Ki-67 proliferation index. Anticancer research. 2009; 29: $1621-5$.

104. Ellis MJ, Tao Y, Luo J, A'Hern R, Evans DB, Bhatnagar AS, et al. Outcome prediction for estrogen receptor-positive breast cancer based on postneoadjuvant endocrine therapy tumor characteristics. Journal of the National Cancer Institute. 2008; 100: 1380-8.

105. Viale G, Giobbie-Hurder A, Regan MM, Coates AS, Mastropasqua MG, Dell'Orto $\mathrm{P}$, et al. Prognostic and predictive value of centrally reviewed Ki-67 labeling index in postmenopausal women with endocrine-responsive breast cancer: results from Breast International Group Trial 1-98 comparing adjuvant tamoxifen with letrozole. Journal of clinical oncology : official journal of the American Society of Clinical Oncology. 2008; 26: 5569-75.

106. Jacquemier J, Charafe-Jauffret E, Monville F, Esterni B, Extra JM, Houvenaeghel G, et al. Association of GATA3, P53, Ki67 status and vascular peritumoral invasion are strongly prognostic in luminal breast cancer. Breast cancer research : BCR. 2009; 11: R23.

107. Ring BZ, Seitz RS, Beck R, Shasteen WJ, Tarr SM, Cheang MC, et al. Novel prognostic immunohistochemical biomarker panel for estrogen receptor-positive breast cancer. Journal of clinical oncology : official journal of the American Society of Clinical Oncology. 2006; 24: 3039-47.

108. Nielsen KV, Ejlertsen B, Moller S, Jorgensen JT, Knoop A, Knudsen H, et al. The value of TOP2A gene copy number variation as a biomarker in breast cancer: Update of DBCG trial 89D. Acta oncologica. 2008; 47: 725-34. 
109. Mueller RE, Parkes RK, Andrulis I, O'Malley FP. Amplification of the TOP2A gene does not predict high levels of topoisomerase II alpha protein in human breast tumor samples. Genes, chromosomes \& cancer. 2004; 39: 288-97.

110. Cardoso F, Durbecq V, Larsimont D, Paesmans M, Leroy JY, Rouas G, et al. Correlation between complete response to anthracycline-based chemotherapy and topoisomerase II-alpha gene amplification and protein overexpression in locally advanced/metastatic breast cancer. International journal of oncology. 2004; 24: 201-9.

111. Knoop AS, Knudsen H, Balslev E, Rasmussen BB, Overgaard J, Nielsen KV, et al. retrospective analysis of topoisomerase Ila amplifications and deletions as predictive markers in primary breast cancer patients randomly assigned to cyclophosphamide, methotrexate, and fluorouracil or cyclophosphamide, epirubicin, and fluorouracil: Danish Breast Cancer Cooperative Group. Journal of clinical oncology : official journal of the American Society of Clinical Oncology. 2005; 23: 7483-90.

112. Ejlertsen B, Jensen MB, Nielsen KV, Balslev E, Rasmussen BB, Willemoe GL, et al. HER2, TOP2A, and TIMP-1 and responsiveness to adjuvant anthracycline-containing chemotherapy in high-risk breast cancer patients. Journal of clinical oncology : official journal of the American Society of Clinical Oncology. 2010; 28: 984-90.

113. Press MF, Sauter G, Buyse M, Bernstein L, Guzman R, Santiago A, et al Alteration of topoisomerase II-alpha gene in human breast cancer: association with responsiveness to anthracycline-based chemotherapy. Journal of clinical oncology : official journal of the American Society of Clinical Oncology. 2011; 29: 859-67.

114. Sotiriou C, Wirapati P, Loi S, Harris A, Fox S, Smeds J, et al. Gene expression profiling in breast cancer: understanding the molecular basis of histologic grade to improve prognosis. Journal of the National Cancer Institute. 2006; 98 : $262-72$.

115. Loi S, Haibe-Kains B, Desmedt C, Lallemand F, Tutt AM, Gillet C, et al. Definition of clinically distinct molecular subtypes in estrogen receptor-positive breast carcinomas through genomic grade. Journal of clinical oncology : official journal of the American Society of Clinical Oncology. 2007; 25: $1239-46$.

116. Winger M, Volz T, Tarel G, Portolan S, Badolato A, Hennessy KJ, et al. Explanation of photon correlations in the far-off-resonance optical emission from a quantum-dot-cavity system. Physical review letters. 2009; 103: 207403.

117. Hennessy MB, Schiml-Webb PA, Deak T. Separation, Sickness, and Depression: A New Perspective on an Old Animal Model. Current directions in psychological science. 2009; 18: 227-31.

118. Rakha EA, Elsheikh SE, Aleskandarany MA, Habashi HO, Green AR, Powe DG, et al. Triple-negative breast cancer: distinguishing between basal and nonbasal subtypes. Clinical cancer research : an official journal of the American Association for Cancer Research. 2009; 15: 2302-10.

119. Rakha EA, Ellis IO. Triple-negative/basal-like breast cancer: review. Pathology. 2009; 41: 40-7.

120. Rakha EA, El-Sayed ME, Green AR, Paish EC, Lee AH, Ellis IO. Breast carcinoma with basal differentiation: a proposal for pathology definition based on basal cytokeratin expression. Histopathology. 2007; 50: 434-8.

121. Romer D, Sznitman S, DiClemente R, Salazar LF, Vanable PA, Carey MP, et al. Mass media as an HIV-prevention strategy: using culturally sensitive messages to reduce HIV-associated sexual behavior of at-risk African American youth. American journal of public health. 2009; 99: 2150-9.

122. Yousefian A, Hennessy E, Umstattd MR, Economos CD, Hallam JS, Hyatt RR, et al. Development of the Rural Active Living Assessment Tools: measuring rural environments. Preventive medicine. 2010; 50 Suppl 1: S86-92.

123. Cheang MC, Voduc D, Bajdik C, Leung S, McKinney S, Chia SK, et al. Basal-like breast cancer defined by five biomarkers has superior prognostic value than triple-negative phenotype. Clinical cancer research : an official journal of the American Association for Cancer Research. 2008; 14: 1368-76.

124. Livasy CA, Karaca G, Nanda R, Tretiakova MS, Olopade OI, Moore DT, et al. Phenotypic evaluation of the basal-like subtype of invasive breast carcinoma. Modern pathology : an official journal of the United States and Canadian Academy of Pathology, Inc. 2006; 19: 264-71.

125. Pan Y, Han J, Zhang Y, Li X-J. [Role of vimentin in tumor metastasis and drug research]. Sheng li ke xue jin zhan [Progress in physiology]. 2010; 41: 413-6.

126. Bergholz Villafane JS. Role of P63 in cell migration and cancer metastasis: BOSTON UNIVERSITY; 2012

127. Perou CM. Molecular stratification of triple-negative breast cancers. The oncologist. 2011; 16 Suppl 1: 61-70.

128. Ho-Yen C, Bowen RL, Jones J. Characterization of basal-like breast cancer: an update. Diagnostic Histopathology. 2012; 18: 104-11.

129. Swenson RR, Rizzo CJ, Brown LK, Payne N, DiClemente RJ, Salazar LF, et al. Prevalence and correlates of HIV testing among sexually active African American adolescents in 4 US cities. Sexually transmitted diseases. 2009; 36: $584-91$.

130. Fan C, Oh DS, Wessels L, Weigelt B, Nuyten DS, Nobel AB, et al. Concordance among gene-expression-based predictors for breast cancer. The New England journal of medicine. 2006; 355: 560-9.

131. Turner NC, Reis-Filho JS, Russell AM, Springall RJ, Ryder K, Steele D, et al. BRCA1 dysfunction in sporadic basal-like breast cancer. Oncogene. 2007; 26: 2126-32.

132. Quach S, Hennessy DA, Faris P, Fong A, Quan H, Doig C. A comparison between the APACHE II and Charlson Index Score for predicting hospital mortality in critically ill patients. BMC health services research. 2009; 9: 129.
133. Maro JC, Platt R, Holmes JH, Strom BL, Hennessy S, Lazarus R, et al. Design of a national distributed health data network. Annals of internal medicine. 2009; 151: 341-4.

134. Hennessy DN, Narayanan B, Rosenberg JM. Automatic implementation of precise grid screens: the four-corners method. Acta crystallographica Section D, Biological crystallography. 2009; 65: 1001-3.

135. Harris LN, You F, Schnitt SJ, Witkiewicz A, Lu X, Soroi D, et al. Predictors of resistance to preoperative trastuzumab and vinorelbine for HER2-positive early breast cancer. Clinical cancer research : an official journal of the American Association for Cancer Research. 2007; 13: 1198-207.

136. West RB, Nuyten DS, Subramanian S, Nielsen TO, Corless CL, Rubin BP, et al. Determination of stromal signatures in breast carcinoma. PLoS biology. 2005; 3: e187.

137. Palmer C, Diehn M, Alizadeh AA, Brown PO. Cell-type specific gene expression profiles of leukocytes in human peripheral blood. BMC genomics. 2006; 7: 115 .

138. Creighton CJ, Li X, Landis M, Dixon JM, Neumeister VM, Sjolund A, et al. Residual breast cancers after conventional therapy display mesenchymal as well as tumor-initiating features. Proceedings of the National Academy of Sciences of the United States of America. 2009; 106: 13820-5.

139. Hennessy BT, Gonzalez-Angulo AM, Stemke-Hale K, Gilcrease MZ, Krishnamurthy S, Lee JS, et al. Characterization of a naturally occurring breast cancer subset enriched in epithelial-to-mesenchymal transition and stem cell characteristics. Cancer research. 2009; 69: 4116-24.

140. Prat A, Perou CM. Deconstructing the molecular portraits of breast cancer. Molecular oncology. 2011; 5: 5-23

141. Prat A, Parker JS, Karginova O, Fan C, Livasy C, Herschkowitz JI, et al. Phenotypic and molecular characterization of the claudin-low intrinsic subtype of breast cancer. Breast cancer research : BCR. 2010; 12: R68.

142. Barnes PJ, Boutilier R, Chiasson D, Rayson D. Metaplastic breast carcinoma: clinical-pathologic characteristics and HER2/neu expression. Breast cancer research and treatment. 2005; 91: 173-8.

143. Gibson GR, Qian D, Ku JK, Lai LL. Metaplastic breast cancer: clinical features and outcomes. The American surgeon. 2005; 71: 725-30.

144. Tavassoli FA. Classification of metaplastic carcinomas of the breast. Pathology annual. 1992; 27(Pt 2): 89-119.

145. Wargotz ES, Norris HJ. Metaplastic carcinomas of the breast. III. Carcinosarcoma Cancer. 1989: 64: 1490-9.

146. Wargotz ES, Deos PH, Norris HJ. Metaplastic carcinomas of the breast. II. Spindle cell carcinoma. Human pathology. 1989; 20: 732-40.

147. Gutman H, Pollock RE, Janjan NA, Johnston DA. Biologic distinctions and therapeutic implications of sarcomatoid metaplasia of epithelial carcinoma of the breast. Journal of the American College of Surgeons. 1995; 180: 193-9.

148. Carter CL, Allen C, Henson DE. Relation of tumor size, lymph node status, and survival in 24,740 breast cancer cases. Cancer. 1989; 63: 181-7.

149. Hennessy BT, Giordano S, Broglio K, Duan Z, Trent J, Buchholz TA, et al. Biphasic metaplastic sarcomatoid carcinoma of the breast. Annals of oncology : official journal of the European Society for Medical Oncology / ESMO. 2006; 17: $605-13$

150. Teschendorff AE, Miremadi A, Pinder SE, Ellis IO, Caldas C. An immune response gene expression module identifies a good prognosis subtype in estrogen receptor negative breast cancer. Genome Biol. 2007; 8: R157.

151. McDonnell TJ, Deane N, Platt FM, Nunez G, Jaeger U, McKearn JP, et al. bcl-2-immunoglobulin transgenic mice demonstrate extended B cell survival and follicular lymphoproliferation. Cell. 1989; 57: 79-88.

152. Henderson S, Rowe M, Gregory C, Croom-Carter D, Wang F, Longnecker R, et al. Induction of bcl-2 expression by Epstein-Barr virus latent membrane protein 1 protects infected B cells from programmed cell death. Cell. 1991; 65: 1107-15.

153. Vanhaesebroeck B, Reed JC, De Valck D, Grooten J, Miyashita T, Tanaka S, et al. Effect of bcl-2 proto-oncogene expression on cellular sensitivity to tumor necrosis factor-mediated cytotoxicity. Oncogene. 1993; 8: 1075-81.

154. Haldar S, Negrini M, Monne M, Sabbioni S, Croce CM. Down-regulation of bcl-2 by p53 in breast cancer cells. Cancer research. 1994; 54: 2095-7.

155. Joensuu H, Pylkkanen L, Toikkanen S. Bcl-2 protein expression and long-term survival in breast cancer. The American journal of pathology. 1994; 145: $1191-8$.

156. Hwang KT, Woo JW, Shin HC, Kim HS, Ahn SK, Moon HG, et al. Prognostic influence of BCL2 expression in breast cancer. International journal of cancer Journal international du cancer. 2012; 131: E1109-19.

157. Silvestrini R, Veneroni S, Daidone MG, Benini E, Boracchi P, Mezzetti M, et al. The Bcl-2 protein: a prognostic indicator strongly related to p53 protein in lymph node-negative breast cancer patients. Journal of the National Cancer Institute. 1994; 86: 499-504

158. Lipponen P, Pietilainen T, Kosma VM, Aaltomaa S, Eskelinen M, Syrjanen K. Apoptosis suppressing protein bcl-2 is expressed in well-differentiated breast carcinomas with favourable prognosis. The Journal of pathology. 1995; 177: 49-55.

159. Berardo $\mathrm{MD}$, Elledge RM, de Moor $\mathrm{C}$, Clark GM, Osborne $\mathrm{CK}_{\text {, Allred } \mathrm{DC}}$ bcl-2 and apoptosis in lymph node positive breast carcinoma. Cancer. 1998; 82: 1296-302.

160. Charpin C, Garcia S, Bonnier P, Martini F, Andrac L, Horschowski N, et al. bcl-2 automated and quantitative immunocytochemical assays in breast carcinomas: correlation with 10-year follow-up. Journal of clinical oncology : official journal of the American Society of Clinical Oncology. 1998; 16: 2025-31. 
161. Neri A, Marrelli D, Roviello F, DeMarco G, Mariani F, DeStefano A, et al. Bcl-2 expression correlates with lymphovascular invasion and long-term prognosis in breast cancer. Breast cancer research and treatment. 2006; 99: 77-83.

162. Dawson SJ, Makretsov N, Blows FM, Driver KE, Provenzano E, Le Quesne J, et al. BCL2 in breast cancer: a favourable prognostic marker across molecular subtypes and independent of adjuvant therapy received. British journal of cancer. 2010; 103: 668-75

163. Abdel-Fatah TM, Perry C, Dickinson P, Ball G, Moseley P, Madhusudan S, et al. $\mathrm{Bcl} 2$ is an independent prognostic marker of triple negative breast cancer (TNBC) and predicts response to anthracycline combination (ATC) chemotherapy (CT) in adjuvant and neoadjuvant settings. Annals of oncology : official journal of the European Society for Medical Oncology / ESMO. 2013; 24: 2801-7.

164. Olivier M, Langerod A, Carrieri P, Bergh J, Klaar S, Eyfjord J, et al. The clinical value of somatic TP53 gene mutations in 1,794 patients with breast cancer. Clinical cancer research : an official journal of the American Association for Cancer Research. 2006; 12: 1157-67.

165. Borresen-Dale AL. TP53 and breast cancer. Human mutation. 2003; 21: 292-300

166. Fitzgibbons PL, Page DL, Weaver D, Thor AD, Allred DC, Clark GM, et al. Prognostic factors in breast cancer. College of American Pathologists Consensus Statement 1999. Archives of pathology \& laboratory medicine. 2000; 124: 966-78.

167. Lacroix M, Toillon RA, Leclercq G. p53 and breast cancer, an update. Endocrine-related cancer. 2006; 13: 293-325.

168. Sayeed A, Konduri SD, Liu W, Bansal S, Li F, Das GM. Estrogen receptor alpha inhibits p53-mediated transcriptional repression: implications for the regulation of apoptosis. Cancer research. 2007; 67: 7746-55.

169. Rahko E, Blanco G, Bloigu R, Soini Y, Talvensaari-Mattila A, Jukkola A. Adverse outcome and resistance to adjuvant antiestrogen therapy in node-positive postmenopausal breast cancer patients-The role of p53. Breast. 2006; 15: 69-75.

170. Lonning PE, Knappskog S, Staalesen V, Chrisanthar R, Lillehaug JR. Breast cancer prognostication and prediction in the postgenomic era. Annals of oncology : official journal of the European Society for Medical Oncology / ESMO. 2007; 18: 1293-306.

171. Kandioler-Eckersberger D, Ludwig C, Rudas M, Kappel S, Janschek E, Wenzel $\mathrm{C}$, et al. TP53 mutation and p53 overexpression for prediction of response to neoadjuvant treatment in breast cancer patients. Clinical cancer research : an official journal of the American Association for Cancer Research. 2000; 6: 50-6.

172. Abbas S, Linseisen J, Slanger T, Kropp S, Mutschelknauss EJ, Flesch-Janys D, et al. Serum 25-hydroxyvitamin D and risk of post-menopausal breast cancer--results of a large case-control study. Carcinogenesis. 2008; 29: 93-9.

173. Bertone-Johnson ER, Chen WY, Holick MF, Hollis BW, Colditz GA, Willett WC, et al. Plasma 25-hydroxyvitamin D and 1,25-dihydroxyvitamin D and risk of breast cancer. Cancer epidemiology, biomarkers \& prevention : a publication of the American Association for Cancer Research, cosponsored by the American Society of Preventive Oncology. 2005; 14: 1991-7.

174. Janowsky EC, Lester GE, Weinberg CR, Millikan RC, Schildkraut JM, Garrett PA, et al. Association between low levels of 1,25-dihydroxyvitamin D and breast cancer risk. Public health nutrition. 1999; 2: 283-91.

175. Lowe LC, Guy M, Mansi JL, Peckitt C, Bliss J, Wilson RG, et al. Plasma 25-hydroxy vitamin D concentrations, vitamin D receptor genotype and breast cancer risk in a UK Caucasian population. European journal of cancer. 2005; 41: $1164-9$

176. Santagata S, Thakkar A, Ergonul A, Wang B, Woo T, Hu R, et al. Taxonomy of breast cancer based on normal cell phenotype predicts outcome. The Journal of clinical investigation. 2014; 124: 859-70.

177. Ni M, Chen Y, Lim E, Wimberly H, Bailey ST, Imai Y, et al. Targeting androgen receptor in estrogen receptor-negative breast cancer. Cancer cell. 2011; 20: 119-31.

178. Allegra JC, Barlock A, Huff KK, Lippman ME. Changes in multiple or sequential estrogen receptor determinations in breast cancer. Cancer. 1980; 45: $792-4$.

179. Moolgavkar SH, Day NE, Stevens RG. Two-stage model for carcinogenesis: Epidemiology of breast cancer in females. Journal of the National Cancer Institute. 1980; 65: 559-69.

180. Paik S, Hartmann DP, Dickson RB, Lippman ME. Antiestrogen resistance in ER positive breast cancer cells. Breast cancer research and treatment. 1994; 31: 301-7.

181. Encarnacion CA, Ciocca DR, McGuire WL, Clark GM, Fuqua SA, Osborne CK. Measurement of steroid hormone receptors in breast cancer patients on tamoxifen. Breast cancer research and treatment. 1993; 26: 237-46.

182. Morrow M, Jordan VC. Molecular mechanisms of resistance to tamoxifen therapy in breast cancer. Archives of surgery. 1993; 128: 1187-91.

183. Nomura $Y$, Tashiro $H$, Shinozuka $K$. Changes of steroid hormone receptor content by chemotherapy and/or endocrine therapy in advanced breast cancer. Cancer. 1985; 55: 546-51.

184. Rakha EA, Elsheikh SE, Aleskandarany MA, Habashi HO, Green AR, Powe DG, et al. Triple-Negative Breast Cancer: Distinguishing between Basal and Nonbasal Subtypes. Clinical Cancer Research. 2009; 15: 2302-10.

\section{Author biography}

Dr. Xiaofeng Dai, Ph.D., is an associate professor at the School of Biotechnology, JiangNan University, China. She got two master degress, one in Biochemistry \& Molecular Biology and the other in Bioinformatics. She received her first doctoral degree in Computational System Biology at Tampere University of Technology, Finland, and the second in Quantitative Methods in Economics at Aalto University, Finland. She conducted her postdoctoral researches at the Institute for Molecular Medicine Finland and the department of Obstetrics and Gynecology in Helsinki University, where she started her career in breast cancer. Dr. Dai got the "Chinese Government Award for Outstanding Self-financed Students Abroad" in 2009, "Best Paper Award" from "the international conference BIOTECHNO", Bucharest, 2009, and received a research financial support of 800000¥ from "National Natural Science Foundation of China" in 2014. Dr. Dai researches focus on breast cancer heterogeneity and subtyping, basal breast cancer stem cell signaling network construction and drug target exploration, as well as bioinformatics studies in biology. 